\title{
THE METEOROLOGICAL SIGNIFICANCE OF FALSE RINGS IN EASTERN REDCEDAR (JUNIPERUS VIRGINIANA L.) FROM THE SOUTHERN GREAT PLAINS, U.S.A.
}

\author{
JESSE R. EDMONDSON \\ Tree-Ring Laboratory, University of Arkansas, Department of Geosciences, 113 Ozark Hall, Fayetteville, \\ Arkansas 72701, USA
}

\begin{abstract}
The growth rings of eastern redcedar (Juniperus virginiana L.) often contain a high frequency of false intra-annual growth bands, which complicates the dendrochronology of this species. However, exactly dated false rings replicated among many trees can reflect major weather changes during the growing season. Sixty-one trees from two sites (Oklahoma and Kansas) were dated and used to compile replicated chronologies of false rings at both locations extending from AD 1700-2000. Falsering events during the modern instrumental era were compared with the daily weather data from nearby stations. Significant false-ring events occurred at both locations during years that experienced a dramatic late-growing season weather reversal, when an extended period of high temperatures and drought was followed by prolonged cool and wet conditions. Synoptic weather maps for these events indicate that all ten replicated false-ring events in the instrumental era occurred during the highly unseasonable penetration of a cold front into the region. However, none of the significant false-ring events occurred in the same year at both sites. These separate false-ring chronologies indicate that there may be phenological differences in the timing of radial growth in redcedar between Kansas and Oklahoma, and that the weather conditions responsible for false-ring formation often occur at the mesoscale and do not often impact central Kansas and northcentral Oklahoma simultaneously.
\end{abstract}

Keywords: Juniperus virginiana, false rings, wood anatomy, phenology, southern Great Plains, drought, heat wave, cool-wet spell.

\section{INTRODUCTION}

The relationship between total ring width and climate has been well documented in the dendroclimatic literature, but fewer studies have reported on the meteorological significance of false rings. These distinctive intra-annual anatomical features can be an obstacle for dendrochronology because they complicate crossdating. However, false rings also present an opportunity to explore growing season weather conditions in more detail. Total ring width is typically related to the integration of meteorological conditions over the entire growing season (Blasing and Fritts 1976; Fritts 2001), but false rings can reflect specific short-term meteorological conditions (Villalba and Veblen 1996; Wimmer et al. 2000; Masiokas and Villalba 2004).

False rings are caused by an interruption of normal cambial activity during the growing season
(Tingley 1937; Schulman 1938; Schweingruber 1996; Schweingruber et al. 2006; Cherubini et al. 2003; De Luis et al. 2007; Rossi and Deslauriers 2007). They may result from a number of environmental stresses including drought, physical damage by insects, disease, wind, or fire (Heinrich and Banks 2006) and forest competition (Copenheaver et al. 2007), however, most may be climatic in origin (Schulman 1938; Barnett 1976; Kramer and Kozlowski 1979). Alternate periods of xylem growth and dormancy may follow favorable and adverse climate conditions (Schweingruber 1996; Rossi and Deslauriers 2007). Periodic drought can cause density fluctuations in the wood (Zahner 1963; Larson 1969; Kuo and McGinnes 1973; Barnett 1976; Kramer and Kozlowski 1979; Villalba and Veblen 1996; Wimmer et al. 2000; Schweingruber et al. 2006). Dry conditions may produce radially smaller tracheids before regular 
latewood formation begins. If these harsh conditions persist, latewood will be produced, and the terminal boundary will be formed for that year. However, if more favorable weather conditions return during the growing season, larger diameter and thinner-walled earlywood growth may resume, resulting in a visible density variation within the ring (i.e. a false ring).

Douglass (1919) found that when winter snowpack was minimal, ponderosa pine (Pinus ponderosa) in Arizona began to form latewood before the end of the usual dry spring period, but would then resume earlywood growth with the onset of summer rains, forming a double ring for that year. Schulman (1938) reported two types of false rings in Monterey Pine (Pinus radiata): 1) a late spring extra ring with a hazy boundary that was formed as a result of temporary unfavorable growth conditions, and 2) an autumn false ring with a sharper boundary, which was found to be the result of exceptional rainfall very late in the growing season (i.e. Sept.-Oct.), which represents an extension rather than an interruption of the growing season. Barnett (1976) was able to experimentally induce false rings when Pinus radiata grown in containers were subjected to periodic drought. Villalba and Veblen (1996) analyzed intra-annual bands in the annual rings of Chilean cedar (Austrocedrus chilensis) in northern Patagonia, Argentina, and developed a falsering chronology from AD 1600-1990. They found that false-ring formation was caused by an unusual climatic pattern characterized by an extremely dry spring followed by a wet summer. Wimmer et al. (2000) used Austrian pine (Pinus nigra) from the northern Alps to improve the reconstruction of early growing season precipitation by adding false-ring occurrence as a "dummy" variable to their regression-based ring-width estimation of precipitation. False rings in the Austrian pine tended to form during similar drythen-wet growing seasons (Wimmer et al. 2000). Masiokas and Villalba (2004) investigated the climatic significance of intra-annual bands in the wood of lenga beech (Nothofagus pumilio) in southern Patagonia and found their formation appears to be a response to anomalously drywarm springs followed by wet-warm summers. De
Luis et al. (2007) reported that false rings in Aleppo pine (Pinus halepensis) from Spain were the result of early autumn precipitation reactivating the cambium after summer drought.

Eastern redcedar (Juniperus virginiana L.) is the most widely distributed native conifer of eastern North America (Little 1971; Figure 1a). Despite its broad native range, the dendrochronology of redcedar can be difficult because of the high frequency of false and missing rings (Weakley 1943; Guyette and McGinnes 1980; Butler and Walsh 1988). Weakley (1943) noted that in Nebraska when the mid-summer months are drier than usual, followed by heavy precipitation during late August, September and early October, double rings frequently occur in juniper. Kuo and McGinnes (1973) found the longitudinal variation of false-ring development in an eastern redcedar tree to be controlled by rainfall conditions. A dry spell followed by a long wet spell was found to produce a false ring through all height levels in the stem. Butler and Walsh (1988) investigated growth rings from 10 trees at each of three sites along an ecotonal transect in west-central Oklahoma and found false rings to be common and correlated amongst the sites.

The presence of intra-annual bands or anatomical structures resembling false rings is more common in conifers growing under stressful conditions, especially near the arid limits of their natural distribution (Fritts 2001; Villalba and Veblen 1996; Masiokas and Villalba 2004). The southern Great Plains are near the western margin of the native range of Juniperus virginiana. This paper presents two false-ring chronologies for eastern redcedar from the southern Great Plains. The objectives of this study are to compare the nature of false-ring occurrence at the two sites, and to identify the forcing mechanism responsible for producing replicated false rings at each site and to explore the potential for relating these intraannual ring features to short-term meteorological events during the growing season.

This analysis will show that highly unseasonable weather extremes occurred during all wellreplicated false-ring episodes contemporaneous with modern instrumental weather observations. These unusual weather conditions are described in 

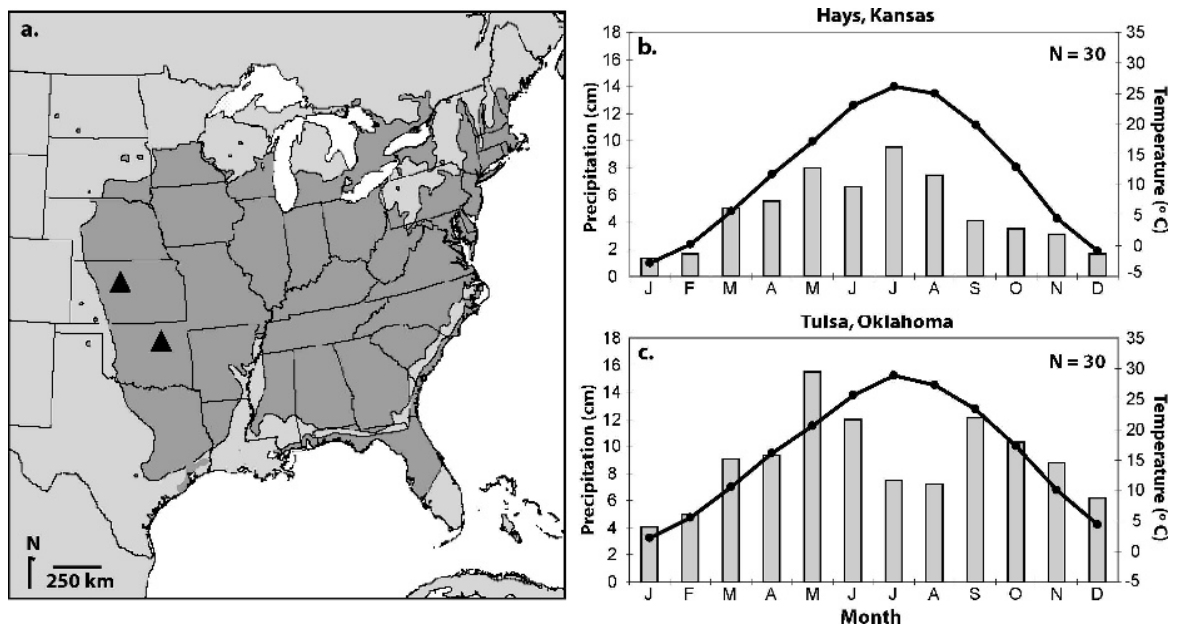

Figure 1. Distribution map of eastern redcedar with climographs from nearby weather stations. (a) The native distribution of $J$. virginiana was mapped by Little (1971). The two sites used in this study (triangles) are separated by $425 \mathrm{~km}$. (b, c) The climographs from the closest weather stations to each site show the differences in precipitation seasonality for these two locations (averages based on 1971-2000, NCDC 2008). The bars represent precipitation $(\mathrm{cm})$ and the dotted line represents temperature $\left({ }^{\circ} \mathrm{C}\right)$.

detail and can reasonably be inferred to have occurred during replicated false-ring events in the pre-instrumental era, as argued by Stahle (1990) who inferred a sequence of climate and weather extremes associated with frost-damaged rings in oaks of the south-central United States. Many of the methods used by Stahle (1990) to document the meteorological significance of frost rings have been applied in this analysis of false rings. LaMarche and Hirschboeck (1984) and Stahle (1990) found that upon comparison with daily meteorological data, it is often possible to identify the specific date on which the damage took place and to characterize the synoptic meteorological situation as well as the antecedent climate conditions that may have contributed to frost ring formation.

\section{MATERIALS AND METHODS}

The Keystone Ancient Forest Preserve (KAFP) site, Oklahoma, is about $425 \mathrm{~km}$ southeast of the Cedar Bluff Reservoir (CBK) site, Kansas (Figure 1a), both of which have distinctive seasonal climatologies. May is the wettest month at Keystone, and July is the wettest month at Cedar Bluff (Figure $1 \mathrm{~b}$ and 1c). The growing season is longer and begins earlier at Keystone Preserve (National Phenology Network 2009).
The Keystone Ancient Forest Preserve is located in the Oklahoma Cross Timbers, which is an ecotone between the eastern deciduous forest and the grasslands of the southern Great Plains. The Keystone Preserve (Osage County, Oklahoma: $36^{\circ} 11.66^{\prime} \mathrm{N}, \quad 96^{\circ} 14.21^{\prime} \mathrm{W}$, elevation = $300 \mathrm{~m}$ a.s.1.) protects some of the highest quality and most extensive tracts of remaining old-growth forest in the entire Cross Timbers ecoregion (Therrell and Stahle 1998; Clark 2005). Redcedar is found in the KAFP on steep, rocky terrain and extremely arid slopes where it is protected from fire and can live to great age ( $>500$ year; Figure 2). A total of 35 correctly dated trees were used for this study. Lobate and sometimes eccentric growth of eastern redcedar at the site caused some of the cores to be omitted from the false-ring analysis.

Cedar Bluff Reservoir is located in southern Trego County, Kansas $\left(38^{\circ} 46.53^{\prime} \mathrm{N}, 99^{\circ} 48.57^{\prime} \mathrm{W}\right)$. The samples from this site were collected and dated by the tree-ring laboratory at INSTAAR in Boulder, Colorado (Woodhouse and Brown 2001; Woodhouse et al. 2002). The final Cedar Bluff chronology consists of 29 cores from 21 living trees, and 10 cross-sections from dead trees (31 trees total). A subsample of 26 of these trees that were dated during the well-replicated period from AD 1700-2000 were used for false-ring analysis. 


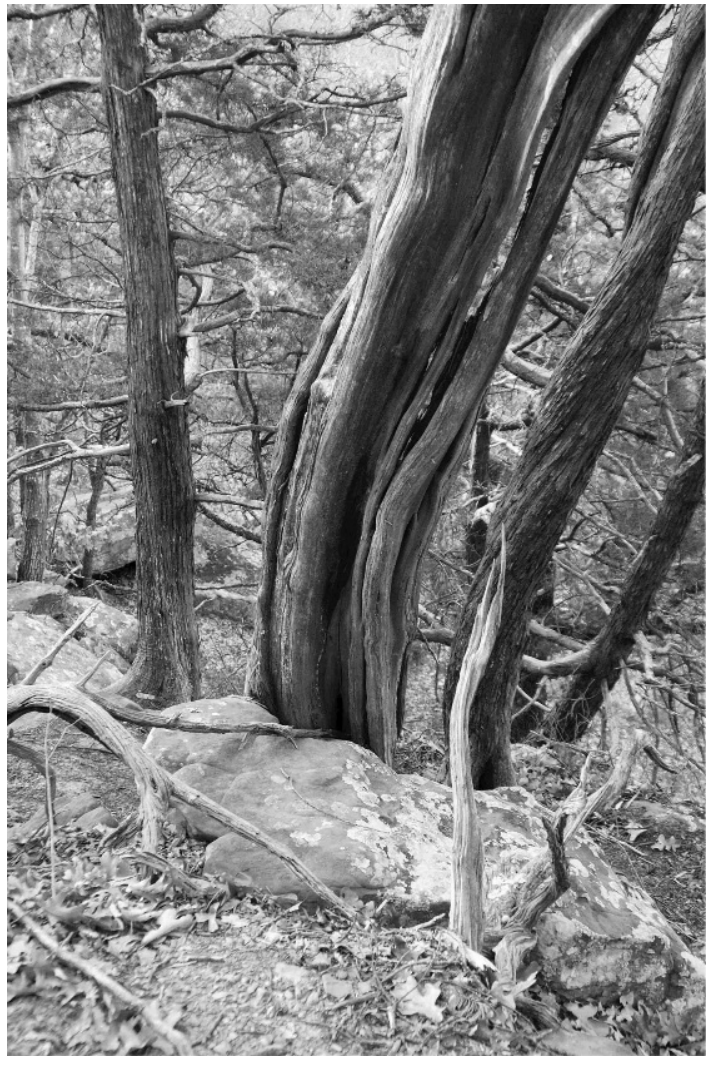

Figure 2. Photograph of ancient eastern redcedar. Old-growth strip-bark $J$. virginiana on steep, rocky, fire-protected slopes at the Keystone Ancient Forest Preserve, Oklahoma.

All cores were mounted and polished. The specimens were dated using the skeleton plot method of crossdating (Stokes and Smiley 1996). Total ring width was measured to the nearest $0.001 \mathrm{~mm}$ with a stage micrometer. Crossdating quality and potential dating errors were evaluated using the computer program COFECHA (Holmes 1983; Grissino-Mayer 2001; Table 1).

Tree-ring chronologies were developed using the program ARSTAN (Cook 1985). The residual chronologies (autoregressive model order zero) for the two sites are only weakly correlated with each other (Figure 3; r $=0.30$ from 1700-2000, $\mathrm{p}<$ 0.0005), but the dating accuracy of the KAFP chronology was further confirmed with a dating check by D. Stahle, by the presence of an exactlydated frost ring at 1826 (Stahle 1990), and by correlation analyses with the post oak [Quercus stellata] chronology developed on site $(\mathrm{r}=0.40$
Table 1. COFECHA descriptive statistics for eastern redcedar at Keystone Ancient Forest Preserve, Oklahoma, and Cedar Bluff, Kansas (KAFP and CBK).

\begin{tabular}{lcc}
\hline \multicolumn{1}{c}{ Site } & KAFP & CBK \\
\hline Chronology length & $1642-2005$ & $1569-2005$ \\
Number of dated series & 59 & 46 \\
Total dated rings checked & 12,866 & 6,049 \\
Average interseries correlation & 0.67 & 0.65 \\
Average Mean Sensitivity & 0.34 & 0.34 \\
\hline
\end{tabular}

from 1700-1995 and $\mathrm{r}=0.50$ from 1850-1995, $\mathrm{p}$ $<0.0005$; Stahle et al. 1985; International TreeRing Data Bank 2009), and the regional tree-ring reconstructed Palmer drought severity indices $(\mathrm{r}=$ 0.37 from 1700-2000, $\mathrm{p}<0.0005$; Cook et al. 2007). The Cedar Bluff, Kansas, record was dated by Lukas, Brown, and Woodhouse. This Great Plains site is remote from other tree-ring chronologies. However, it is significantly correlated with local instrumental precipitation totals for October-September $(\mathrm{r}=0.66$ from 1896-2000 for Kansas climate division 5, $\mathrm{p}<0.0005$; National Climatic Data Center 2009) and with the regional PDSI reconstruction $(\mathrm{r}=0.41$ from $1700-2000, \mathrm{p}$ $<0.0005$; Cook et al. 2007).

Two 300-year false-ring chronologies were developed based on exactly-dated false-ring years found in at least two trees at each site. The period from 1700-2000 was adequately replicated at both sites. A significance test was adopted from Stahle (1990), using the binomial distribution to calculate the 95\% confidence intervals $(C I)$ around the proportion of false rings in a given year:

$$
C I=1 \pm\left(\sqrt{\frac{p \times(1-p)}{n}}\right) \times 2
$$

where $p$ is the proportion of dated trees with anatomical evidence for a false ring in any given year, and $n$ is the total number of trees dated to that year (Ott 1984; Stahle 1990). The confidence intervals were calculated separately for data from each site, and the width of the confidence intervals is sensitive to the sample size of dated trees at each site $(n)$. To be significant, $p$-CI must exceed the random background frequency of false-ring occurrence. The background frequency was calculated as 

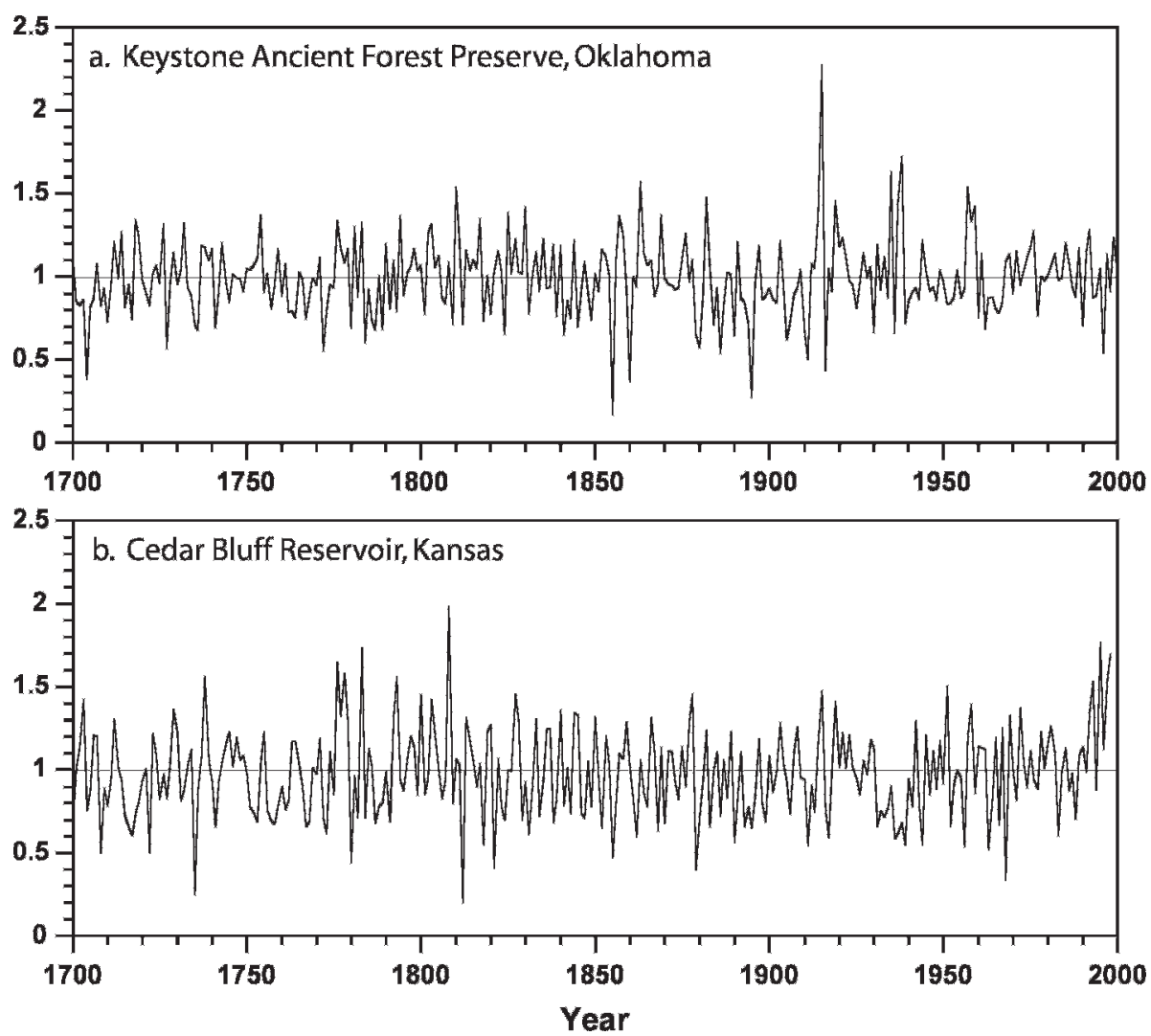

Figure 3. Residual tree-ring chronologies of Juniperus virginiana. The detrended residual tree-ring chronologies for Cedar Bluff Reservoir, Kansas, and the Keystone Ancient Forest Preserve, Oklahoma, are shown. Both chronologies are correlated with growing season moisture conditions during the instrumental era.

the simple ratio of all false rings to the total number of dated rings. False rings can be expected to occur in any given year at this approximate frequency if their interannual occurrence is entirely random (Stahle 1990). This statistical test isolated only false-ring events that were replicated amongst a significant proportion of trees.

The meteorological significance of the replicated false-ring events was also analyzed. Significant false-ring events that occurred during the modern instrumental period were compared with the daily maximum and minimum temperature and daily precipitation records from the closest available weather stations. Tulsa International Airport, Oklahoma, was used for the KAFP (1938-2000; approximately $25 \mathrm{~km}$ distant) and the weather station at Hays, Kansas, was used for
Cedar Bluff Reservoir (1892-2000; approximately $45 \mathrm{~km}$ distant, National Climatic Data Center 2008). The 1914 event at the KAFP occurred before the Tulsa Airport record began so additional stations were used. Stillwater and $\mathrm{Pa}$ whuska, Oklahoma, are both available for 1914. Because the KAFP lies between these two stations, a simple average of the daily instrumental weather data from Stillwater and Pawhuska was used to estimate daily weather conditions at the KAFP in 1914 (National Climatic Data Center 2008).

\section{RESULTS AND DISCUSSION}

\section{Growth Ring Anatomy of Juniperus virginiana}

Juniperus virginiana has distinct annual growth ring boundaries preceded by a gradual 
transition from earlywood to latewood (Figure 4). The latewood zone in this species is generally narrow and displays little interannual variability. The sharp transition from flattened thick-walled latewood cells of one year to the larger cell lumen and thinner walls of the earlywood of the next growing season defines the terminal boundary for true annual rings. Other structures seen in the growth ring anatomy of this species (transverse surface) include homocellular unisereate rays and axial parenchyma cells that are found either solitary or arranged in loosely grouped tangential bands (Figure 4).

For the purpose of this study, any distinct density variation in the earlywood and latewood recognized with a reflected light microscope using 7-30× variable zoom magnification was identified as a false ring. False rings are typically distinguished from true annual rings given adequate sample preparation and magnification because they lack an abrupt termination to the latewood locally along the suspected ring boundary. Some false rings were only faint density variations easily identified as double rings (Figure 4a). Other false rings had more abrupt ring boundaries and were only detected as false rings by careful microscopic examination and crossdating (Figure 4b). The location and abruptness of the false rings varied by tree and calendar date, and with further research might provide insight into the timing and magnitude of the meteorological anomaly.

False-ring frequency has been reported to be greater in the juvenile growth of trees (Larson 1969; Priya and Bhat 1998; Wimmer et al. 2000; Heinrich and Banks 2006), and appears to be the result of the close proximity of the primary and secondary meristems at the sampled height on the stem during early years of growth. The pith is left behind as the primary meristem ascends longitudinally up the stem. Secondary thickening at this point on the stem where both meristems are so close together is hypersensitive to its environment and is therefore more susceptible to producing density variations within a ring (Kuo and McGinnes 1973; Schweingruber et al. 2006). This phenomena was noted in this study in some specimens. When all first-formed rings on a specimen exhibited false rings, these years were
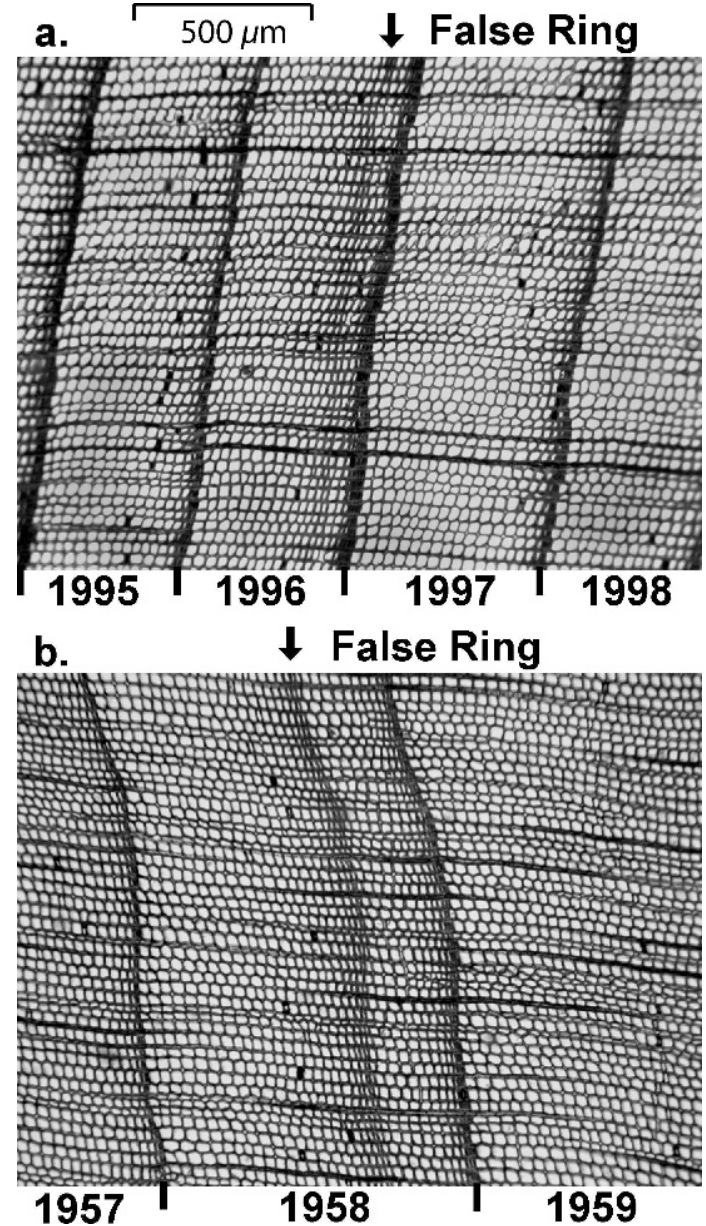

Figure 4. Photomicrographs of false rings in eastern redcedar. Annual growth-ring anatomy for two $J$. virginiana specimens from the Keystone Preserve (transverse surface, illustrating tracheids, unisereate rays, axial parenchyma cells, earlywood, latewood, and false rings; growth proceeded from left to right; $30 \times$ magnification). The annual rings from 1994-1998 are illustrated in (a) for specimen HOS57A. The 1996 false ring was present in 32\% of trees from KAFP and is seen here as a faint density variation involving three or four tracheids. This false ring is anatomically obvious when compared to the sharp ring boundaries of true annual rings (a). The 1958 false ring (b, HOS50A) is present in $50 \%$ of the samples from KAFP and is sometimes indistinguishable on anatomical criteria from a true ring when viewed with a reflected light microscope. Crossdating is necessary for false-ring identification when the anatomy is ambiguous.

omitted from the chronology (up to ten years on some samples). The significance test used for this study, which emphasizes the crossdating of false rings among trees, also minimized the impact of juvenile false rings on the derived chronology. 


\section{False-Ring Chronologies}

The two false-ring chronologies are presented in Figure 5. The chronology for Keystone Preserve includes nine significant false-ring events (a total of 239 false rings were identified out of 6914 total rings on 35 trees for a background frequency of 0.03 , Figure $5 \mathrm{a}$ ). Ten significant false-ring years were identified at Cedar Bluff (610 total false rings were identified out of a total of 3932 rings on 26 trees, and a higher background frequency of 0.15 , Figure $5 b$ ). The difference in the background frequency of false rings between these two sites is remarkable and might be caused in part by a more variable growing season climate in central Kansas. It is also interesting that some redcedar trees in Oklahoma did not form any false rings for over 200 year until 1948 and 1958, when false rings occurred in $50 \%$ of the dated trees at the site (e.g. trees IRV04 and IRV14). Remarkably, none of the significant false-ring events occurred in the same year at both KAFP and CBK.

\section{Meteorological Significance of False Rings}

Daily instrumental weather data are available for the four most recent false-ring events in Oklahoma and for the six most recent events in Kansas (1930 from Kansas was omitted from the weather analysis because of missing values). The daily data were examined during the growing season to identify the weather conditions concurrent with false-ring formation. The significant false-ring events from both sites show a similar growing season weather reversal that could be responsible for false-ring formation (Figures 6 and 7). In all cases, a mid-growing season heat wave and drought developed. These heat waves were then followed by a period of much lower temperatures and in some cases torrential rainfall. A composite average of these mid-growing season weather reversals in Kansas and Oklahoma summarizes the conditions that appear to have stimulated the formation of false rings (Figure 6 and 7).

The accuracy of the false-ring chronologies as proxies for growing season anomalies was tested by first defining the minimum temperature and precipitation thresholds associated with false-ring formation, and then searching the daily instrumental meteorological record for similar events not recorded by false rings (see Stahle 1990 for further details). Minimum threshold criteria were calculated for each site based on the daily meteorological data for significant event years. In Oklahoma, four years appear to have fulfilled the meteorological criteria for false-ring formation from 1938-2000. Only one year, 1977, was not matched by significant false rings at the Keystone Preserve, roughly suggesting an accuracy of $75 \%$ for the false-ring registration of late-growing season weather reversals (as specifically defined here). The minimum meteorological criteria were met for 1977, but a significant proportion of trees did not form false rings. A closer investigation of the daily weather data indicates that the 1977 growing season overall was not as extreme as the weather reversals associated with 1948, 1958, and 1996. In particular, May of 1977 was much wetter than the other three years.

In Kansas, false rings were found in most years that fulfilled the minimal meteorological criteria for false-ring formation from 1892-2000 (20 of 24), but only seven years registered false rings in a significant proportion of trees, suggesting an accuracy of only $29 \%$. A larger sample of dated trees might improve the agreement between the false-ring chronology and the years of anomalous weather in Kansas. Significant differences in the weather between the tree-ring site and the weather station might also explain some of the inaccuracy. A weather station at each tree-ring site would be optimal for this analysis.

The intensity of false-ring formation at both sites in terms of the fraction of trees that exhibit false rings and the degree of cell-wall lignification, appears to be related approximately to the intensity of the weather reversal, i.e. the more dramatic the weather reversal, the higher the proportion of trees at the site that formed a false ring for the given year. Similar results were reported by Masiokas and Villalba (2004) in their study of Nothofagus pumilio from southern Patagonia.

The 1996 event in Oklahoma is the only falsering episode that did not experience significant rainfall associated with the cool weather change 

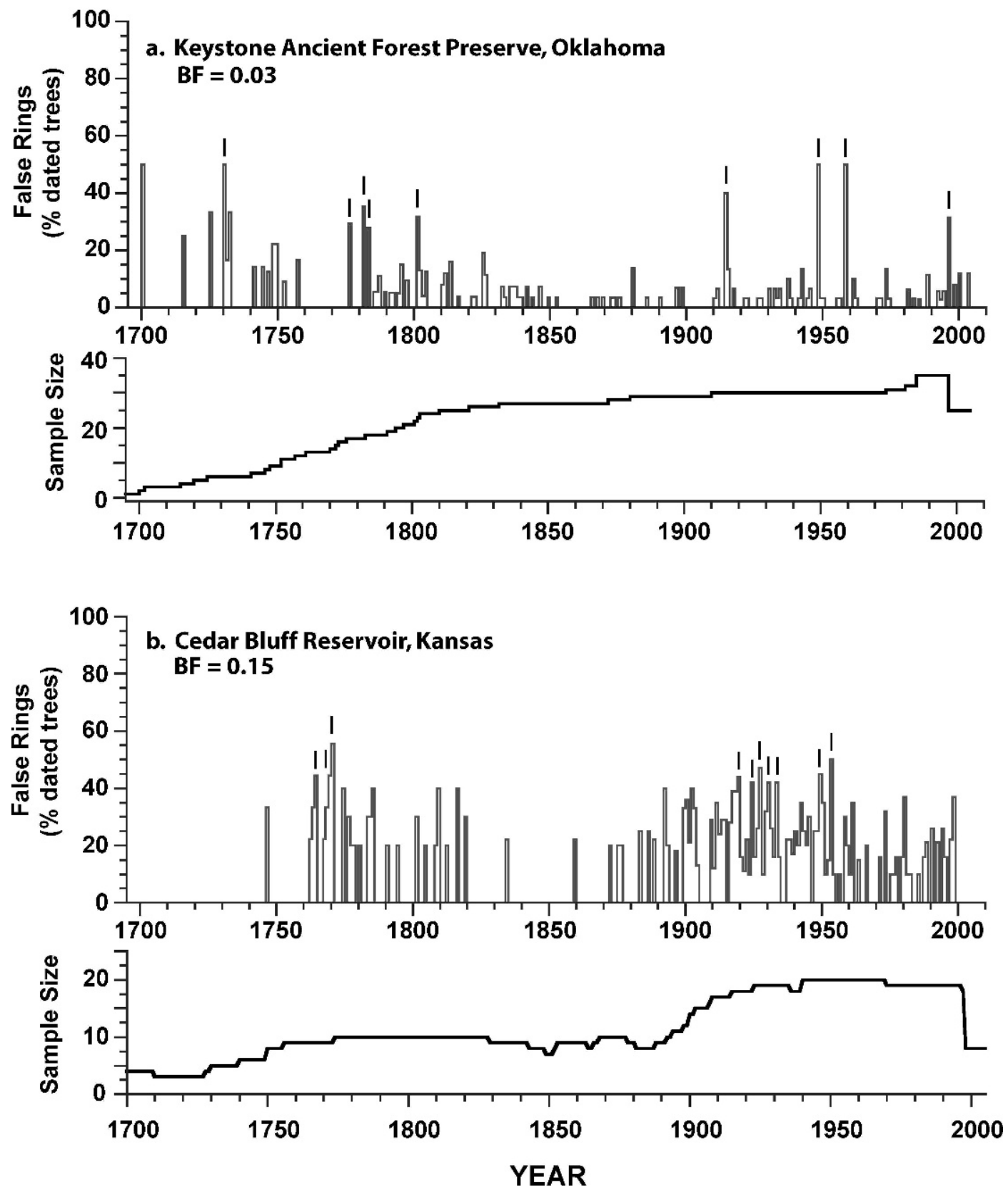

Figure 5. False-ring chronologies. The false-ring chronologies for Keystone Preserve and Cedar Bluff are plotted as the percent of dated trees with a false ring in a given year, along with the sample size of dated trees. All false-ring years shown above were found in at least two trees at the site. The co-occurrence of false rings during nine years in Oklahoma and ten years in Kansas was statistically significant (see ticks) when tested against the randomized background frequency (BF) of false rings using confidence intervals calculated with the binomial distribution (see Equation 1). False rings were much more common at Cedar Bluff than at Keystone $(\mathrm{BF}=0.15$ vs. 0.03 , respectively), but none of the significant false-ring events occurred at both sites. 

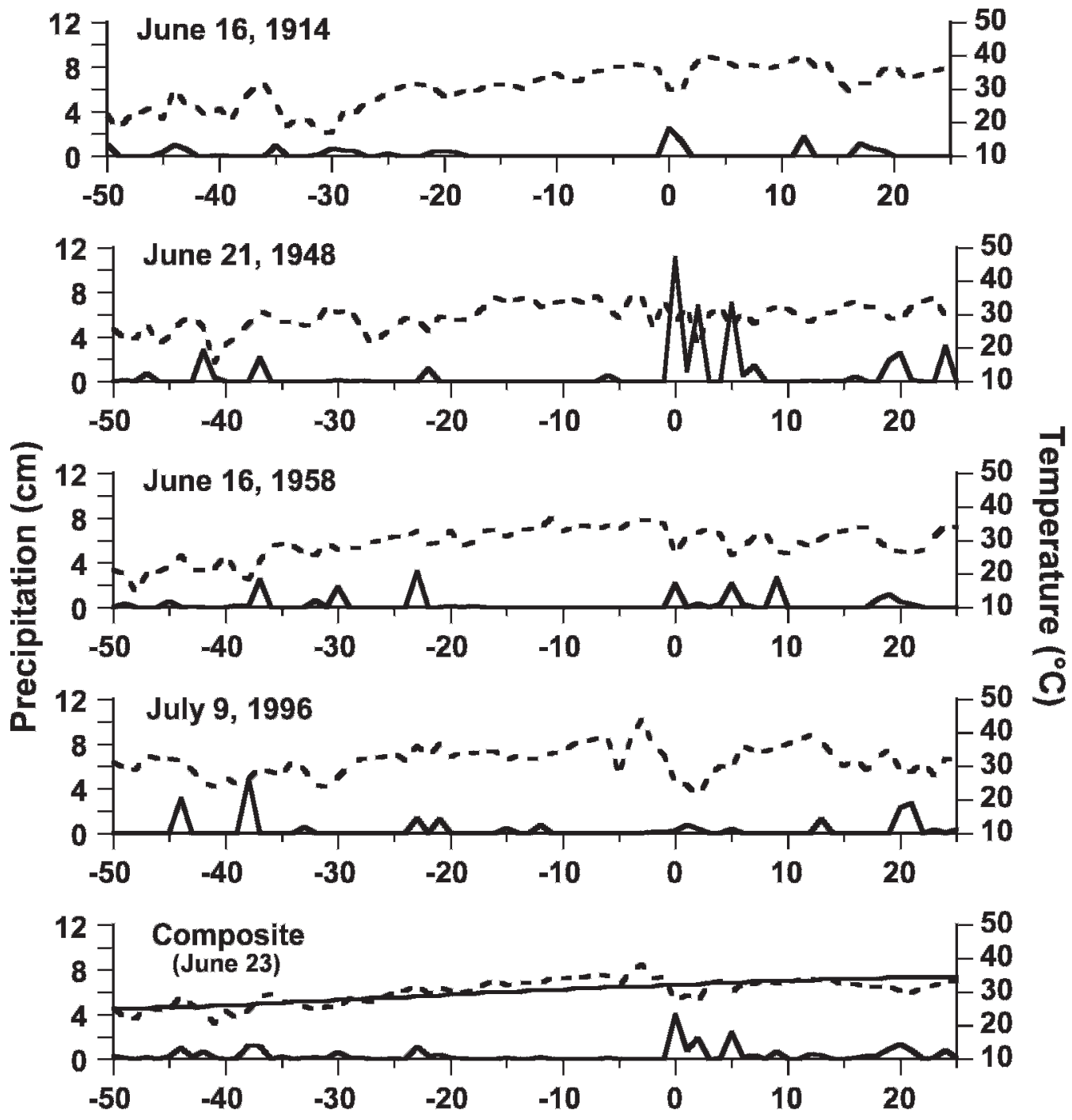

Event Day

Figure 6. Meteorology of Oklahoma false-ring events. The daily precipitation and maximum temperature records from Tulsa International Airport, Oklahoma, for the 50 days before and the 25 days after the meteorological event believed responsible for false-ring formation at the Keystone Preserve. These time series are event centered, where event day zero was the first day of the unseasonable weather reversal. The daily precipitation and temperature data for these four events have been averaged in the composite plot (bottom) before and after the average date for false-ring events in Oklahoma (June 23). The mean daily maximum temperature for Tulsa before and after the average date for false-ring events in Oklahoma (June 23) is also plotted (smooth black line).

based on the Tulsa International Airport record (Figure 6). In 1996, false rings were found in a low proportion of trees and they were less intense, sometimes evident only as a faint density variation
(Figure 4a). In contrast, the cool and wet reversal in 1958 was recorded as a false ring in a higher proportion of samples, and the false ring was often anatomically similar to a true ring (Figure $3 b$ ). 

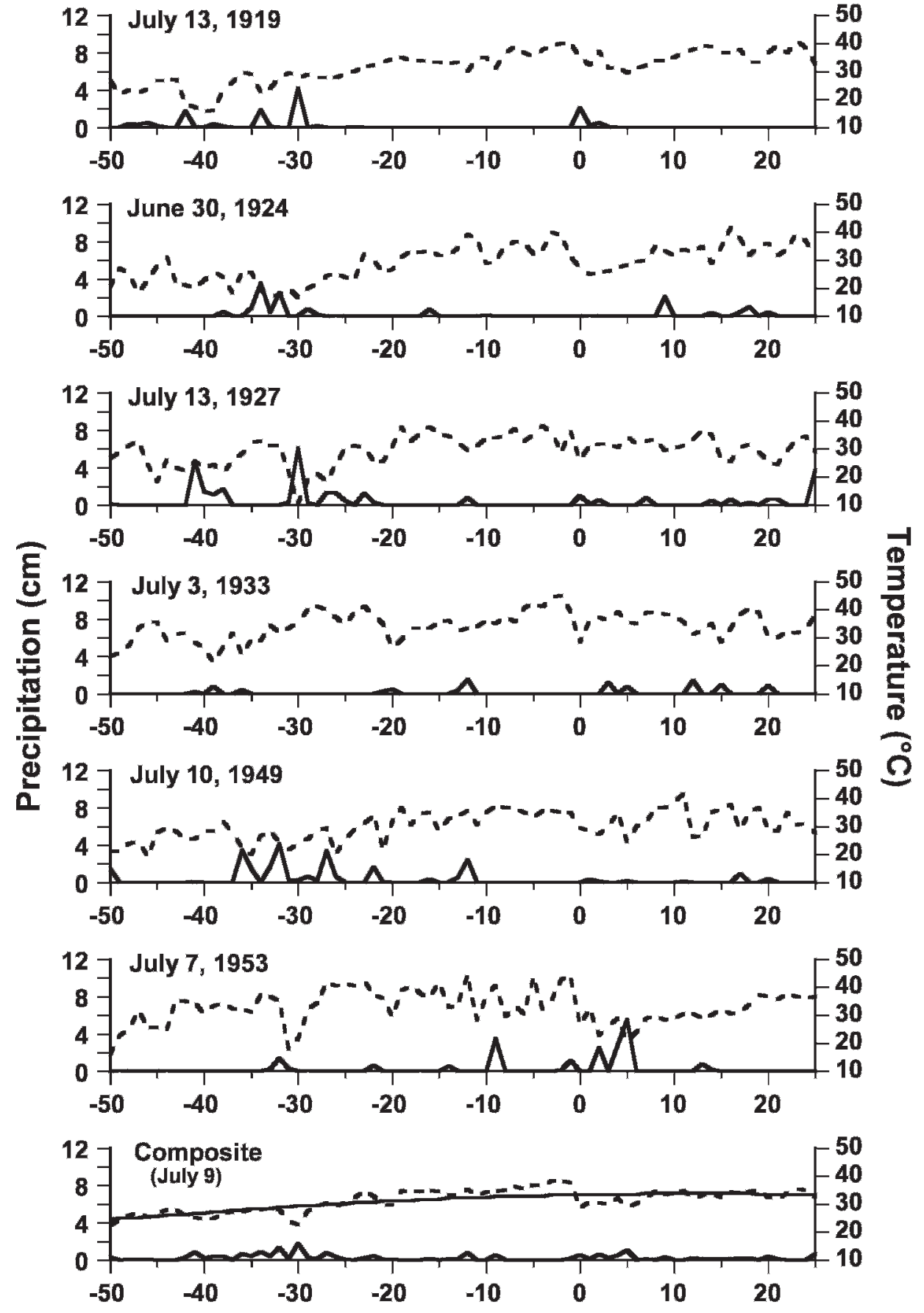

Event Day

Figure 7. Meteorology of Kansas false-ring events. The daily precipitation and maximum temperature records from the weather station at Hays, Kansas, for the 50 days before and the 25 days after the meteorological event believed responsible for false-ring formation at Cedar Bluff Reservoir, Kansas. These time series are event-centered, where event day zero was the first day of the unseasonable weather reversal. The daily precipitation and temperature data for these six events have been averaged in the composite plot (bottom) before and after the average date for false-ring events in Kansas (July 9). The mean daily maximum temperature for Hays before and after the average date for false-ring events in Kansas (July 9) is also plotted (smooth black line). 


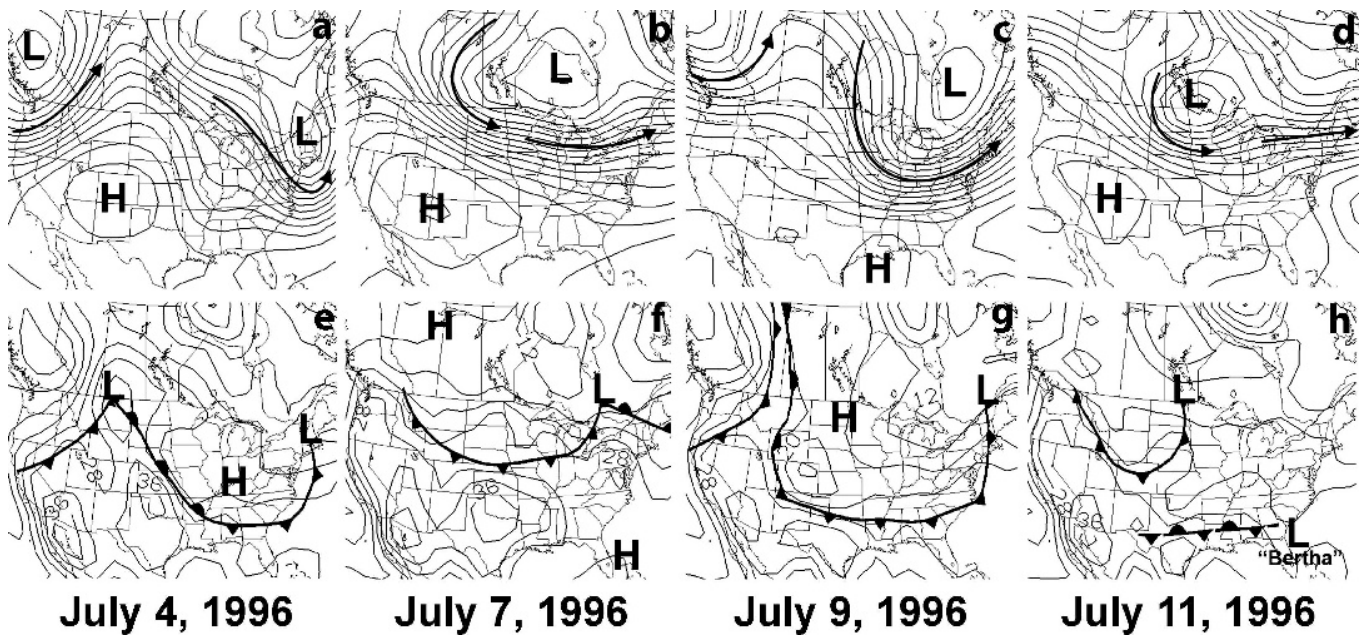

Figure 8. Synoptic meteorology of the 1996 false-ring event in Oklahoma. The $500 \mathrm{mb}(\mathrm{a}-\mathrm{d})$ and surface weather maps (e-h) for four selected dates during the 1996 false-ring event in Oklahoma (valid at 7:00 pm CDT, Kalnay et al. 1996). These synoptic maps depict the evolution of this weather reversal from hot and dry to cool and wet conditions during mid-summer over Oklahoma. This succession of cold fronts is highly unseasonable for the southern Great Plains during July.

Crossdating was often required to prove it was a false ring.

The radial location of significant false rings within the annual growth ring seems to be approximately related to the calendar date of the meteorological event. The two latest events in the Oklahoma record were June 21, 1948, and July 9, 1996. The false rings in these years formed later within the ring (sometimes within the latewood) than in most samples at this site (see 1996, Figure 4a). The 1914 and 1958 false-ring events, which both occurred during mid-June, often registered in the growth ring before pure latewood formation (see 1958, Figure 4b). Villalba and Veblen (1996) found similar results in their falsering analysis of Austrocedrus chilensis in northern Patagonia.

\section{Synoptic Meteorology of Weather Reversals Associated with False Rings}

Dramatic changes from hot-dry to cool-wet conditions during the late growing season of the southern Great Plains may coincide with a major reversal in the general circulation over North America, analogous to the extraordinary climate and weather reversals associated with frost rings and major volcanic eruptions (LaMarche and
Hirschboeck 1984) as well as false spring and frost damaged rings (Stahle 1990). Three largescale weather systems seem capable of causing the extraordinary weather associated with false-ring formation in this region. A slow-moving or stalled frontal boundary, a mesoscale convective complex (MCC), or conceivably an early season tropical system could deliver the heavy rainfall and temperature reversals observed during false-ring formation. MCCs are large, organized, self-enhancing thunderstorm complexes that are typically much larger than an individual thunderstorm (Maddox 1980). These thunderstorm complexes can deliver a significant fraction of the total annual rainfall in a matter of hours (Maddox 1980).

The historical daily weather maps published by the US Weather Bureau (NOAA Central Library 2008) were used to characterize the synoptic meteorology of the ten modern false-ring events from the southern Great Plains. The weather reversals attributed to false-ring events in these ten years were all the result of unseasonable cold fronts. The cold front associated with the 1996 false-ring event in Oklahoma is the most recent and well-documented, and, in general terms, is representative of the synoptic meteorology of the other nine events. Figure 8 illustrates the synoptic evolution of this meteorological event 

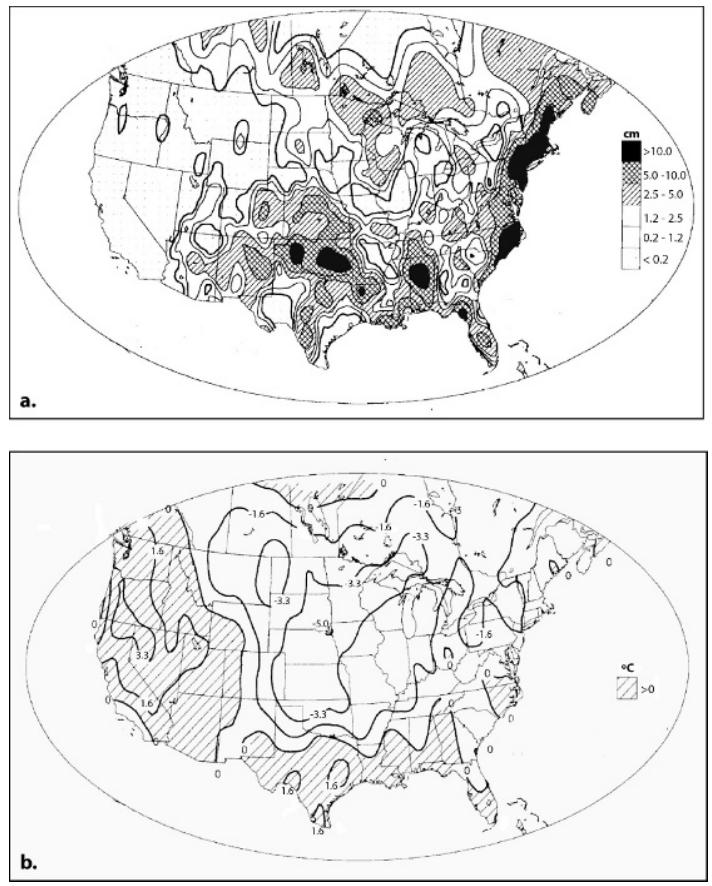

Figure 9. Maps of total precipitation and average daily temperature departures for the 1996 false-ring event in Oklahoma. (a) Total precipitation amounts (cm) for the falsering event week of July 7-13, 1996 (precipitation period 12 GMT Sun. to 12 GMT Sun.). Notice the high weekly precipitation totals recorded over Oklahoma, near the Keystone Preserve. (b) Isotherms of average daily temperature departures $\left({ }^{\circ} \mathrm{C}\right)$ from the instrumental mean (1961-1990) for July 7-13, 1996. Temperatures across the Great Plains were $2.0-5.5^{\circ} \mathrm{C}$ below normal during this week. These figures are both from the Weekly Crop and Weather Bulletin (1996) published July 16, 1996, but have been modified to SI units.

from hot-dry to cool-wet conditions over the southern Great Plains. On July 4, a classic omega block (Namias 1982) is seen over the western and central US in the $500 \mathrm{mb}$ height field, which would divert disturbances into Canada and favor intense heat over the Southern Plains (Figure 8a). On July 6 (not shown), while still under the midcontinental ridge, daily maximum temperatures peaked at over $43.3^{\circ} \mathrm{C}\left(110^{\circ} \mathrm{F}\right)$ in northeast Oklahoma, because of strong southwesterly flow at the surface enhanced by "pre-frontal warming" (heating caused by adiabatic compression by the approaching air mass). On July 7, a final day of intense heat gripped the Southern Plains, producing several daily maximum temperature records (Figures $8 \mathrm{~b}$ and $8 \mathrm{f})$. "Triple-digit heat" $\left(\geq 100^{\circ} \mathrm{F}\right.$ or $\geq 38^{\circ} \mathrm{C}$ ) lasted eight days in Oklahoma City and ten days in Wichita Falls, Texas (Weekly Weather and Crop Bulletin 1996).

The ridge of high pressure during the heat wave was replaced by a series of low pressure troughs in the upper air circulation, with associated cold fronts and air mass changes at the surface from July 7-14, 1996 (Figures 8c, d and $8 \mathrm{~g}, \mathrm{~h}$ ). By July 9 (the "event day" in Figure 6) significant rainfall was recorded across the region and the most significant 24-hour drop in daily maximum temperature $\left(-7.8^{\circ} \mathrm{C},-14^{\circ} \mathrm{F}\right)$ was recorded as a result of a cool Canadian air mass plunging south down the Great Plains (Figures 8c and $8 \mathrm{~g}$ ). Rainfall was recorded on July 10 at Tulsa as the front passed through the area and the daily maximum temperature was only $25.6^{\circ} \mathrm{C}\left(78^{\circ} \mathrm{F}\right)$. On July 11, the next system approached the region and the lowest daily maximum temperature was recorded for the "cool spell" at $21.1^{\circ} \mathrm{C}\left(70^{\circ} \mathrm{F}\right.$, Figure $8 \mathrm{~d}$ and $8 \mathrm{~h}$ ). July 15 was the first day in a week when temperatures rose above $32.2^{\circ} \mathrm{C}$ $\left(90^{\circ} \mathrm{F}\right)$.

In 1996, the core of the warm spell began June 28 and lasted through July 7, the average daily maximum temperature for this period was $36.4^{\circ} \mathrm{C}\left(98^{\circ} \mathrm{F}\right)$, and no rainfall was recorded at Tulsa Airport during this heat wave. For the week of July 7-15, the southern Great Plains experienced heavy rainfall totals and below average temperature conditions (Figures 9a, b; Weekly Weather and Crop Bulletin 1996). Although only $1.75 \mathrm{~cm}$ (0.6 in.) of rainfall were recorded for this period at Tulsa International Airport, it is likely that the Keystone Preserve received greater totals. The presence of tropical moisture and stalled frontal boundaries fueled torrential rainfall across the south-central US during the cool-wet episode. Rainfall was recorded every day over the region from July 7-14. In Oklahoma City, the 7-day rainfall total (July 8-14) reached $21.4 \mathrm{~cm}$ (8.42 in.), including daily record totals on July 10,11 , and $14(2.79,3.02$, and 1.98 in. or $7.1,7.7$, and $5.0 \mathrm{~cm}$ respectively; Figure 9a; Weekly Crop and Weather Bulletin 1996).

The 1948 event in Oklahoma was perhaps the most significant mid-growing season weather reversal over the Southern Plains during the era 


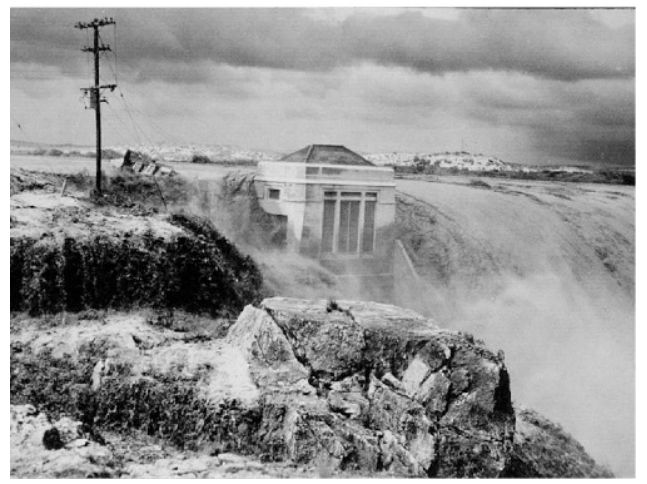

Figure 10. Devil's River Flood of 1948 near Del Rio, Texas. On June 24, 1948, the Devils River flooded over Lake Walk Dam near Del Rio, Texas (photograph: USGS 61 by Breeding, USGS 2008). Peak discharge was measured at over $441,000 \mathrm{cfs}$ after nearly $53 \mathrm{~cm}$ (21 in.) of rainfall fell in this region in a 48-hour period, associated with the same meteorological event that caused false-ring formation in J. virginiana at the Keystone Ancient Forest Preserve in Oklahoma.

of instrumental weather observation (Figure 6). In late June a stalled frontal boundary was in place over the region. Tulsa International Airport recorded over $25.4 \mathrm{~cm}$ (10 in.) of rainfall and a decline in daily maximum temperature of $5.5^{\circ} \mathrm{C}$ $\left(10^{\circ} \mathrm{F}\right.$, June 21,1948$)$. On June 22, 1948, the front page of the Daily Oklahoman (1948) showed a map of the state flood area with the caption:

\footnotetext{
Nine persons were swept to their deaths just east of Hydro, Oklahoma, yesterday when Deep Rock creek was swelled to a raging torrent by 19 in. $(48 \mathrm{~cm})$ of rain. At Kingfisher, continued heavy rains sent two small creeks out of their banks and forced 225 families from their homes. Others were evacuated at Wewoka, Weleetka, and Henryetta. Geary, Oklahoma, reported 11 in. $(28 \mathrm{~cm})$ of rain, combining with Hyrdo's fall to push the long dry South Canadian River out of its banks near Newcastle. Flood conditions existed on the North Canadian above and below Oklahoma City. Flood stage exists on the Arkansas, Cimarron, Verdigris, and Grand Rivers, plus creeks in eastern and north central Oklahoma.
}

A reported $53.3 \mathrm{~cm}$ (21 in.) fell in just over 48 hour during this same meteorological event as far south as Del Rio, Texas, where the torrential rains caused widespread flooding over Oklahoma and Texas (Figure 10, June 24, 1948). Tropical air from the Gulf streamed into this region several days before a $700 \mathrm{mb}$ trough in the westerlies moved into the Devil's River drainage. On the morning of June 24, 1948, heavy rainfall moved northwest to southeast into the prevailing lowlevel flow, indicating a MCC was set up with the first thunderstorms in the early morning hours (USGS 2008). The storms eventually built into the oncoming low level jet from the Gulf throughout the day yielding the extremely high rainfall totals measured from this event.

\section{SUMMARY AND CONCLUSIONS}

Juniperus virginiana of the southern Great Plains may produce false rings in years that experience a dramatic weather reversal in the late growing season. False-ring chronologies were developed for the past 300 years in Oklahoma and Kansas based on the exactly dated and replicated co-occurrence of intra-annual density variations at each location. These false-ring chronologies were used to investigate the unseasonable synoptic weather conditions responsible for false-ring formation at each site. Significant false-ring events at both sites occurred when there was an intense heat wave and drought during the mid-growing season, followed by an unseasonable cool-wet spell when daily maximum temperatures fell as much as $16^{\circ} \mathrm{C}\left(29^{\circ} \mathrm{F}\right)$ and heavy rainfall often occurred. All 10 replicated false-ring events that occurred during the modern instrumental era were found to be caused by the unseasonable penetration of cold fronts deep into the southern Great Plains. Although the tree-ring chronologies developed from these two sites were weakly correlated, the false-ring chronologies were unique for each site. This probably reflects the differences in the phenology of radial cedar growth and in the mesoscale weather conditions between the two sites that are separated by $425 \mathrm{~km}$ (NPN 2009; NCDC 2009).

Total ring width and density tend to integrate weather and climate conditions over the entire growing season and do not routinely provide short-term meteorological information (Fritts 2001). The most useful timescale for synoptic climatological analysis is weeks-to-months, a period that is not typically differentiated by tree rings (Hirschboeck et al. 1996). The relatively sudden anatomical changes associated with false 
rings during the middle of the growing season may provide a means to identify specific meteorological events. At each site used for this study, significant false-ring events occurred during a fairly narrow window of time within the growing season. In Oklahoma, the false-ring events during the 20th Century occurred between June 16 and July 9. The 20th Century false-ring events in Kansas occurred slightly later in the growing season, ranging from June 30 to July 13. This separation in timing may be attributed to differences in the phenology of tree growth between the two sites (NPN 2009). Detailed monitoring of the cambial activity at these sites would help constrain the timing of falsering events.

The potential to map synoptic weather extremes from a spatial array of false-ring chronologies in North American conifers is considerable. Thousands of samples have already been collected, and exactly dated, and are known to contain replicated false-ring information. This includes extensive collections of eastern redcedar, baldcypress (Taxodium distichum and Taxodium mucronatum) from the southeastern United States and Mexico, and Douglas-fir (Pseudotsuga menziesii) and ponderosa pine from western North America. The development of a network of well-replicated false-ring chronologies could provide interesting details on growing season weather conditions during the historic and prehistoric eras.

\section{ACKNOWLEDGMENTS}

Supported in part by NSF grant numbers ATM-0400713 and ATM-0753399, a University of Arkansas Honors College undergraduate research grant, the University of Arkansas Department of Geosciences Jack D. Mussett scholarship, the Ozark Society Neil Compton Scholarship, and financial support from Jeanne and Wayne Erickson. Thank you to Connie Woodhouse and Jeff Lukas for sharing the wood collection from Cedar Bluff, Kansas, for this analysis. A special thanks goes to David Stahle for his insight, advice, and friendship throughout the course of this project. His dissertation on frost rings provided a helpful framework for much of the methodology. Dorian Burnette provided valuable assistance with the meteorological discussion. I am also grateful to Malcolm Cleaveland for his comments and criticisms toward this paper. I would also like to recognize Alan Edmondson, Dave Patton, Daniel Griffin, Richard Styron, Mark Spond, Stephen James, and Jackson Jennings for their help in the field. Finally, thank you to my family and friends who have offered their continued love and support over the years.

\section{REFERENCES CITED}

Anonymous, 1948. June 22, 1948. Daily Oklahoman. Oklahoma City, Oklahoma; 1 pp.

Barnett, J. R., 1976. Rings of collapsed cells in Pinus radiata stemwood from lysimeter-grown trees subjected to drought. New Zealand Journal of Forestry Science 6:461-465.

Blasing, T. J., and H. C. Fritts, 1976. Reconstruction of past climate anomalies in the North Pacific and Western North America from tree-ring data. Quaternary Research 6:563-579.

Butler, D. R., and S. J. Walsh, 1988. The use of eastern redcedar in tree-ring study in Oklahoma. Prairie Naturalist 20:47-56.

Cherubini, P., B. Gartner, R. Tognetti, W. Schoch, O. U. Bräker, and J. L. Innes, 2003. Identification, measurement, and interpretation of tree-rings in woody species from Mediterranean climates. Biological Reviews 78(1):119-148.

Clark, S. L., 2005. Characteristics of the Keystone Ancient Forest Preserve, an old-growth forest in the Cross Timbers of Oklahoma. Natural Areas Journal 25:165-175.

Cook, E. R., R. Seager, M. A. Cane, and D. W. Stahle, 2007. North American drought reconstructions, causes, and consequences. Earth Science Reviews 81:93-134.

Cook, E. R., 1985. A Time Series Approach to Tree-Ring Standardization. Ph.D. dissertation. University of Arizona, Tucson.

Copenheaver, C. A., E. A. Pokorski, J. E. Currie, and M. D. Abrams, 2006. Causation of false ring formation in Pinus banksiana: A comparison of age, canopy class, climate and growth rate. Forest Ecology and Management 236:348-355.

De Luis, M., J. Gricar, K. Cufar, and J. Raventos, 2007. Seasonal dynamics of wood formation in Pinus halepensis from dry and semi-arid ecosystems in Spain. IAWA Journal 28(4):389-404.

Douglass, A. E., 1919. Climatic cycles and tree growth: A study of the annual rings of trees in relation to climate and solar activity. Carnegie Institute of Washington 289(1):18-20.

Fritts, H. C., 2001. Tree Rings and Climate. Blackburn Press, Caldwell, New Jersey.

Grissino-Mayer, H. D., 2001. Evaluating crossdating accuracy: A manual and tutorial for the computer program COFECHA. Tree-Ring Research 57(2):205-221.

Guyette, R. P., and E. A. McGinnes, 1980. A climate history of Boone County, Missouri, for a tree-ring analysis of eastern redcedar. Wood and Fiber 12:17-26.

Heinrich, I., and J. C. G. Banks, 2006. Tree-ring anomalies in Toona ciliata. IAWA Journal 27:213-231. 
Hirschboeck, K. K., N. Fenbiao, M. L. Wood, and C. A. Woodhouse, 1996. Synoptic dendroclimatology: Overview and prospectus. In Tree Rings, Environment, and Humanity, edited by J. S. Dean, D. M. Meko, and T. W. Swetnam, pp. 205-223. Radiocarbon, University of Arizona, Tucson.

Holmes, R. L., 1983. Computer-assisted quality control in tree-ring dating and measurement. Tree-Ring Bulletin 43: 69-78.

International Tree-Ring Data Bank, 2009. National Oceanic and Atmospheric Administration. Website: www.ncdc.noaa. gov/paleo/treering.html. US Department of Commerce.

Kalnay, E., M. Kanamitsu, R. Kistler, W. Collins, D. Deaven, L. Gandin, M. Iredell, S. Saha, G. White, J. Woollen, Y. Zhu, A. Leetmaa, B. Reynolds, M. Chelliah, W. Ebisuzaki, W. Higgins, J. Janowiak, K. Mo, C. Ropelewski, J. Wang, R. Jenne, and D. Joseph, 1996. The NCEP/NCAR 40-year reanalysis project. Bulletin of the American Meteorological Society 77:437-471.

Kuo, M. L., and E. A. McGinnes, 1973. Variation of anatomical structure of false rings in eastern red cedar. Wood Science 5:205-210.

LaMarche, V. C., and K. K. Hirschboeck, 1984. Frost rings in trees as records of major volcanic eruptions. Nature 307: 121-126.

Larson, P. R., 1969. Wood Formation and the Concept of Wood Quality, Bulletin No. 74, Yale University, School of Forestry; $54 \mathrm{pp}$.

Little, E. L. Jr, 1971. Atlas of United States Trees-Conifers and Important Hardwoods. US Department of Agriculture, Washington, D.C., Miscellaneous Publication 1; 1146 pp.

Maddox, R. A., 1980. Mesoscale convective complexes. Bulletin of the American Meteorological Society 61:1374-1387.

Masiokas, M., and R. Villalba, 2004. Climatic significance of intra-annual bands in the wood of Nothofagus pumilio in southern Patagonia. Trees-Structure and Function 18:696-704.

Namias, J., 1982. Anatomy of Great Plains protracted heat waves (especially the 1980 U.S. summer drought). Monthly Weather Review 110:824-838.

National Climatic Data Center (NCDC), 2009. Website: www. ncdc.noaa.gov/oa/ncdc.html. US Department of Commerce.

National Oceanic and Atmospheric Administration Central Library, 2008. US Daily Weather Maps Project. Website: docs.lib.noaa.gov/rescue/dwm/data_rescue_daily_weather_ maps.html US Department of Commerce.

National Phenology Network (NPN), 2009. USA National Phenology Network. Website: www.usanpn.org/, National Coordinating Office, University of Arizona.

Ott, L., 1984. An Introduction to Statistical Methods and Data Analysis. Duxbury Press, Boston.

Priya, P. B., and K. M. Bhat, 1998. False ring formation in teak (Tectona grandis L.f.) and the influence of environmental factors. Forest Ecology and Management 108:215-222.
Rossi, S., and A. Deslauriers, 2007. Intra-annual time scales in tree-rings. Editorial. Dendrochronologia 25:75-77.

Schulman, E., 1938. Classification of false annual rings in Monterey Pine. Tree-Ring Bulletin 4(3):4-7.

Schweingruber, F. H., 1996. Tree Rings and Environment, Dendroecology. Swiss Federal Institute for Forest, Snow, and Landscape Research, Birmensdorf; 609 pp.

Schweingruber, F. H., A. Börner, and E. D. Schulze, 2006. Atlas of Woody Plant Stems; Evolution, Structure, and Environmental Modifications. Springer, Berlin.

Stahle, D. W., J. G. Hehr, G. G. Hawks, M. K. Cleaveland, and J. R. Baldwin, 1985. Tree-Ring Chronologies for the Southcentral United States. Tree-Ring Laboratory, Office of the State Climatologist, University of Arkansas, Fayetteville.

Stahle, D. W., 1990. The Tree-Ring Record of False Spring in the Southcentral USA. Ph.D. dissertation, Arizona State University, Tempe.

Stokes, M. A., and T. L. Smiley, 1996. An Introduction to Treering Dating. University of Arizona Press, Tucson.

Therrell, M. D., and D. W. Stahle, 1998. A predictive model to locate ancient forests in the Cross Timbers of Osage County, Oklahoma. Journal of Biogeography 25:847-854.

United States Geological Survey, 2008. Major and Catastrophic Storms and Floods in Texas: Flood Photos by City. USGS 61, photographed by Breeding June 24, 1948. Website: pubs. usgs.gov/of/2003/ofr03193/cd_files/USGS_Storms/phototable. htm, United States Department of Interior.

Villalba, R., and T. T. Veblen, 1996. A tree-ring record of dry spring-set summer events in the forest-steppe ecotone, northern Patagonia, Argentina. In Tree Rings, Environment, and Humanity, edited by J. S. Dean, D. M. Meko, and T. W. Swetnam, pp. 107-116. Radiocarbon, University of Arizona, Tucson.

Weakley, H. E., 1943. A tree-ring record of precipitation in western Nebraska. Journal of Forestry 41:816-819.

Weekly Weather and Crop Bulletin, 1996. US Department of Commerce and Department of Agriculture, 83(28): July 16, 1996.

Wimmer, R., G. Strumia, and F. Holawe, 2000. Use of false rings in Austrian Pine to reconstruct early growing season precipitation. Canadian Journal of Forest Research 30: 1691-1697.

Woodhouse, C. A., and P. M. Brown, 2001. Tree-ring evidence for Great Plains drought. Tree-Ring Research 57:89-103.

Woodhouse, C. A., J. L. Lukas, and P. M. Brown, 2002. Drought in the western Great Plains, 1845-56: Impacts and implications. Bulletin of the American Meteorological Society 83:1485-1493.

Zahner, R., 1963. Internal moisture stress and wood formation in conifers. Forest Products Journal 13:240-247.

Received 19 August 2008; accepted 27 September 2009. 